\title{
Granisetron Transdermal Patch
}

National Cancer Institute

\section{Source}

National Cancer Institute. Granisetron Transdermal Patch. NCI Thesaurus. Code C80377.

A transdermal system containing granisetron, a selective serotonin (5-HT) receptor antagonist, with antiemetic activity. Upon application of the transdermal patch to the skin and subsequent release into the bloodstream, granisetron selectively binds to and blocks the 5 - $\mathrm{HT}$ subtype $3(5-\mathrm{HT} 3)$ receptors located in the vagus nerve terminal and in the vomiting center in the central nervous system (CNS). By preventing stimulation of 5-HT3 receptors, this agent is able to suppress chemotherapy-induced nausea and vomiting. 